УДК 630*561.24(470.311)

РЕЗУЛЬТАТЫ ДЕНДРОХРОНОЛОГИЧЕСКИХ ИССЛЕДОВАНИЙ

В ДРЕВОСТОЯХ БЕРЕЗЫ НА ТЕРРИТОРИИ ДОМОДЕДОВСКОГО ЛЕСНИЧЕСТВА МОСКОВСКОЙ ОБЛАСТИ

Румянцев Д.Е., Фролова В.А., Денисова Н.Б.

Мытищинский филиал ФГБОУ ВО МГТУ им. Н.Э. Баумана

(национальный исследовательский университет), Мытищи, е-таil: dendro15@list.ru

Береза повислая (Betula pendula Roth.) относится к рассеянно-сосудистым древесным породам, и на образцах древесины ее кольца относительно слабо различимы. Это обусловило относительно малую исследованность данного вида на территории Русской равнины дендрохронологическими методами. В то же время в условиях рекреационных лесов и лесопарков Москвы и Московской области этот вид является одним из важнейших лесообразователей. В данной статье излагаются результаты дендрохронологических исследований в древостоях березы на территории Домодедовского лесничества Московской области. На основании выполненных исследований было установлено, что все модельные древостои относятся к VI классу возраста. Древостои всех четырех пробных площадей несмотря на наличие отличий в формируемых с их участием фитоценозов по флористическому составу подлеска и живого напочвенного покрова, характеризуются сходными условиями для роста и развития деревьев березы. Дендроклиматический анализ показал, что водный дефицит в июне и июле является главным лимитирующим рост экологическим фактором, вызывающим плохой рост и плохое состояние деревьев березы. В целом сильные и однозначные связи между изменчивостью конкретных отдельных метеопараметров и изменчивостью величины годичных колец отсутствуют, что типично для насаждений в неэкстремальных условиях местопроизрастания. Для улучшения состояния насаждений, стимуляции радиального прироста в целях скорейшего зарастания ран и механических повреждений стволов может быть рекомендован полив деревьев в июне и июле в те годы, когда сумма осадков за эти месяцы будет значительно ниже среднемноголетних показателей по г. Москве.

Ключевые слова: радиальный прирост, дендрохронология, береза повислая, леса Московской области

\title{
RESULTS OF DENDROCHRONOLOGICAL STUDIES IN BIRCH STANDS AT THE DOMODEDOVO FORESTRY OF THE MOSCOW REGION
}

\section{Rumyantsev D.E., Frolova V.A., Denisova N.B.}

Mytishchi branch of Bauman Moscow State Technical University

(National Research University of Technology), Mytishchi,e-mail: dendro15@list.ru

Birch (Betula pendula Roth.) belongs to disseminated vascular tree species and is relatively poorly distinguishable on wood samples. This led to relatively little research of this species on Russian plain by dendrochronological methods. At the same time, in conditions of recreational forests and woodland parks of Moscow and Moscow region this specie is one of the most important forest-forming species. Dendrochronological diagnosis for features of radial growth in these conditions has a great interest for forest science theory as well as for forestry practices. The results of dendrochronological investigations in betula satnds from Domodedovo forestry of Moscow region are disclosed in this article. On the basis of the conducted studies it was established, that all model stands consist of VI age class. The trees of all four test plots, despite the presence of differences in the phytocenoses formed with their participation in the floristic composition of the undergrowth and live ground cover, are characterized by similar conditions for the growth and development of birch trees. Dendroclimatic analysis showed that water scarcity in June and July is the main limiting factor of ecological growth, which can cause poor growth and poor condition of birch trees. In general, there are no strong and unambiguous connections between the variability of specific individual meteorological parameters and the variability of annual rings, which is typical for plantations in non-extreme conditions of vegetation. To improve the condition of plantations, to stimulate radial growth in order to accelerate the overgrowing of wounds and mechanical damage to trunks, watering trees in June and July can be recommended in those years when the amount of precipitation over these months will be significantly lower than the average long-term indicators in Moscow.

Keywords: radial growth, dednrochronology, Betula pendula, forests of Moscow region

Древесина березы относится к рассеянно-сосудистым древесным породам. Годичные кольца у видов с рассеянно-сосудистой древесиной слабо различимы, и они менее популярны, чем кольце-сосудистые и хвойные древесные породы [1]. Это обусловлено тем, что для проявления годичных колец на дендрохронологических образцах от рассеянно-сосудистых древесных пород необходимы более трудоемкие методы об- работки поверхности, что было отмечено еще Д.И. Менделеевым [1], а также позднее А.Н. Тихомировым и В.А. Жолтко [1]. Трудности распознавания годичных колец обусловили низкий интерес дендрохронологов к закономерностям изменчивости радиального прироста у березы и других рассеянно-сосудистых пород, тем не менее ряд исследований в этом направлении был всетаки выполнен как дендрохронологически- 
ми методами [2-4], так и с использованием дендроклиматической информации [5-7]. В данной статье изложены отдельные результаты анализа изменчивости радиального прироста березы в условиях Домодедовского района Московской области, частично она развивает положения предыдущей [8].

Согласно лесорастительному районированию Московской области, леса Домодедовского района относятся к району северозападной окраины Подмосковной Мещёры с маломощным покровом водно-ледниковых отложений, лежащим на размытой морене. Березовые леса относятся ко вторичным. Район исследования вплотную примыкает к городу Москве. В работе академика Л.П. Рысина и соавторов [9] отмечалось, что березняки на территории Москвы ничем существенно не отличаются от экосистем-аналогов, находящихся за пределами города.

Целью настоящего исследования была диагностика особенностей роста березы повислой в условиях Домодедовского лесничества Московской области на основе данных об изменчивости годичных колец. Задачами исследования был отбор образцов древесины, построение временных рядов изменчивости годичных колец, анализ изменчивости радиального прироста, в том числе и анализ влияния климатических факторов на формирование годичных колец березы.

\section{Материалы и методы исследования}

Методика отбора образцов, построения древесно-кольцевых хронологий и их анализа с использованием табличного процессора Excel была аналогична методикам, использовавшимся ранее [1]. Было заложено четыре пробных площади, с каждой из которых было отобрано по 15 кернов древесины, по одному с каждого учетного дерева. При выделении типов березовых лесов ориентировались на работу Л.П. Рысина и соавторов [9]. Первым шагом было выделение участков отличающихся по составу растительного покрова, вторым заложение временных пробных площадей, третьим отбор кернов древесины, четвертым отбор образцов древесины, пятым измерение ширины годичных колец и получение древесно-кольцевых хронологий, и шестым - анализ полученных данных. Использовались традиционные для лесоводственной дендрохронологии методы математической обработки данных [1].

Пробная площадь 1 принадлежит к такому типу леса, как березняк хвощевый. Преобладание хвоща полевого (Equisetum arvense L.) в составе живого напочвенного покрова указывает на тяжелые, кислые и достаточно увлажненные почвы.

Пробная площадь 2 относится к такому типу леса, как березняк разнотравный. По сравнению с ПП 1 благодаря наличию земляники лесной (Fragaria vesca L.), ландыша майского (Convallaria majalis L.) и гравилата городского (Geum urbanum L.) почву данного участка следует рассматривать как менее кислую и менее увлажненную. О большем плодородии почвы на данном участке по сравнению с ПП 1 говорит более развитый подлесок.

Пробная площадь 3 расположена в таком типе леса, как березняк широкотравноволосистоосоковый. Живой напочвенный покров на данном участке насыщен неморальными видами, что говорит о высоком плодородии почвы, достаточном уровне увлажнения и низкой кислотности почвы. О плодородии почвы свидетельствует примесь липы в составе древостоя и развитый подлесок с преобладанием лещины.

Пробная площадь 4 расположена в березняке разнотравно-волосистоосоковом. Почвы данного участка могут быть охарактеризованы как наиболее сухие, древостой здесь низкополнотный и испытывает сильную рекреационную нагрузку, о чем свидетельствует наличие рудеральных видов: одуванчика лекарственного (Taraxacum officinale Web. Ex Wigg.), лопуха большого (Arctium lappa L.), живучки ползучей (Ajuga reptans L.), манжетки обыкновенной (Alchemilla vulgaris L.).

\section{Результаты исследования и их обсуждение}

В результате измерения ширины годичных колец нами были получены временные ряды радиального прироста. Они отражают колебания ширины годичного кольца по годам у учетных деревьях. Полученные временные ряды приведены на графиках (рис. 1-4).

На основе графиков можно сделать вывод, что все учетные деревья имеют приблизительно один возраст. Отличия по длине временных рядов радиального прироста могут быть связаны с разной скоростью роста в высоту и разновременным достижением учетными деревьями высоты 1,3 м (на которой производился отбор керна). Наиболее длинная хронология из всех исследованных имеет первое годичное кольцо, датируемое 1948 г. В целом класс возраста исследованных древостоев оценивается как VI. 

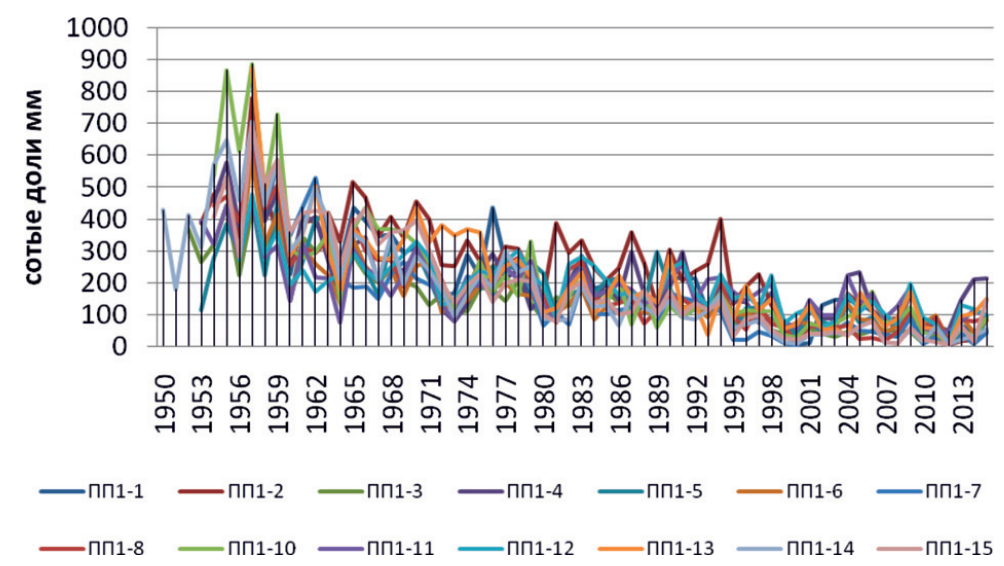

Рис. 1. Динамика радиального прироста у учетных деревьев на пробной площзади № 1

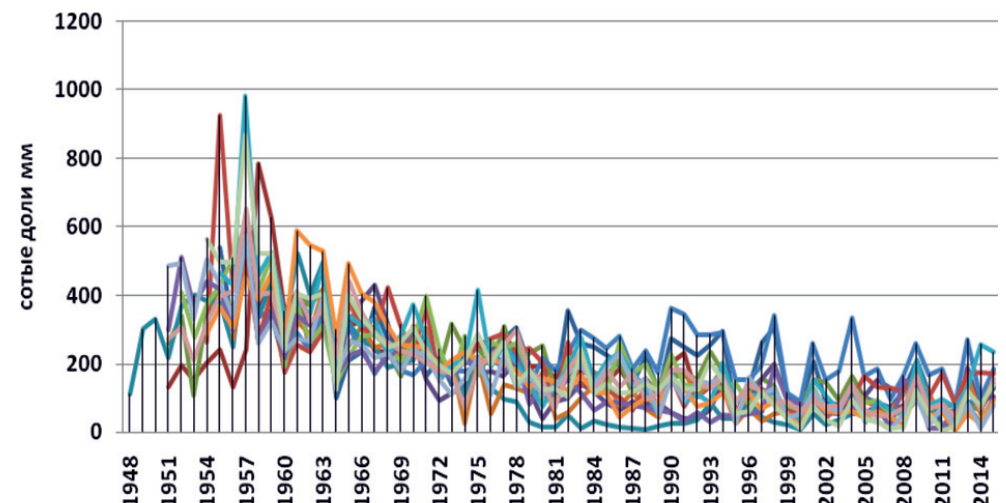

$\begin{array}{lllll}-\Pi \Pi 2-1 & -\Pi \Pi 2-2 & -\Pi \Pi 2-3 & -\Pi \Pi 2-5 & -\Pi \Pi 2-6 \\ -\Pi \Pi 2-7 & -\Pi \Pi 2-8 & -\Pi \Pi 2-9 & -\Pi \Pi 2-10 & -\Pi \Pi 2-11 \\ -\Pi \Pi 2-12 & -\Pi \Pi 2-13 & -\Pi \Pi 2-14 & -\Pi \Pi 2-15 & -\Pi \Pi 2-16\end{array}$

Рис. 2. Динамика радиального прироста у учетных деревьев на пробной площади № 2

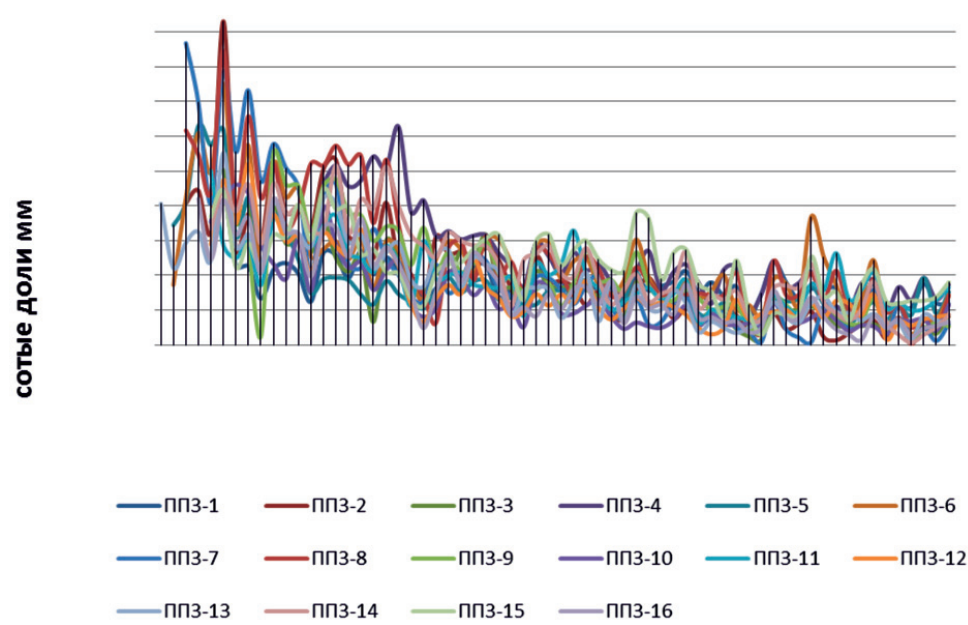

Рис. 3. Динамика радиального прироста у учетных деревьев на пробной площцади № 3 


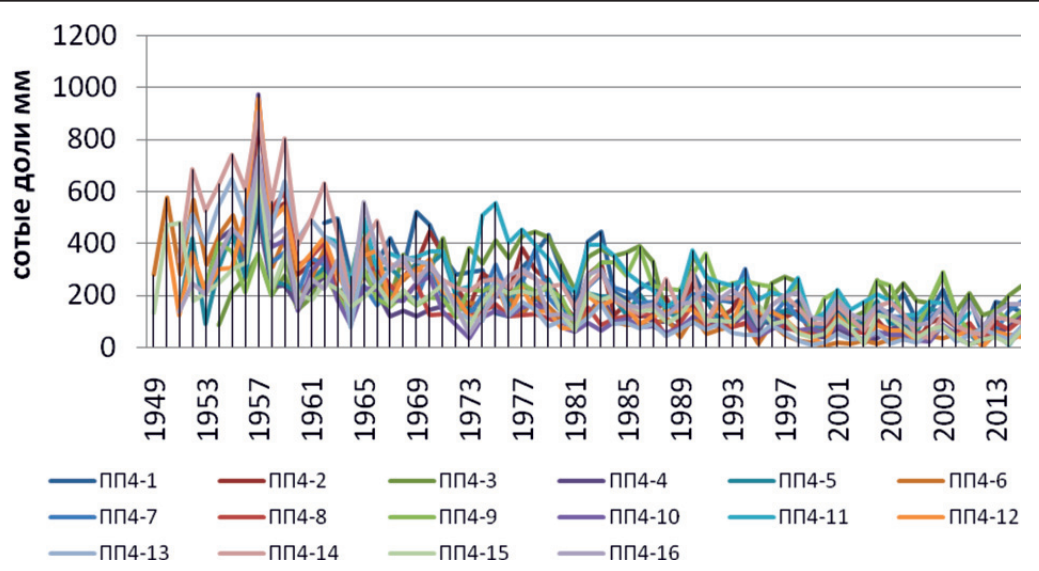

Рис. 4. Динамика радиального прироста у учетных деревьев на пробной площади № 4

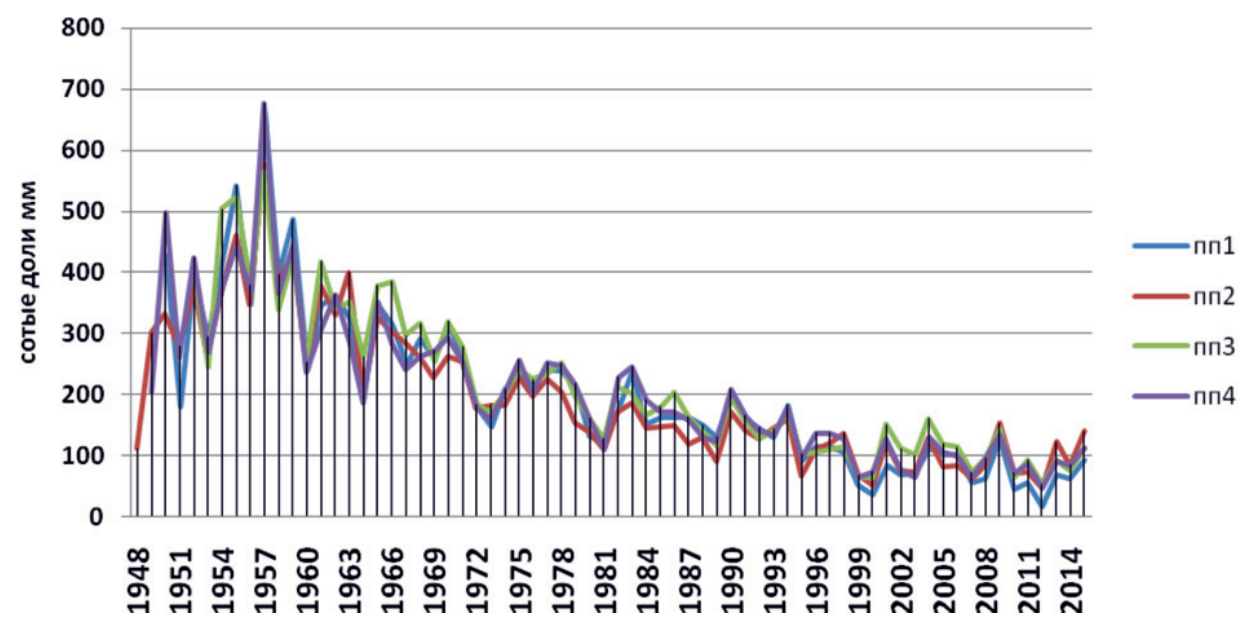

Рис. 5. Динамика радиального прироста у учетных деревьев на пробных площадях

Ряды радиального прироста, полученные для отдельных деревьев на каждой пробной площади, послужили основой для расчета средней хронологии по ширине годичного кольца по данной пробной площади. Такого рода временные ряды позволяют ретроспективно охарактеризовать динамику продуктивности деревьев на пробных площадях. Полученные временные серии графически отражены на рис. 5.

По результатам анализа можно отметить, что наибольшей шириной годичного кольца характеризуются деревья на пробной площади № 2. Занимаемый ею участок характеризуется как обладающий наиболее благоприятными условиями для роста и развития насаждений березы. Менее благоприятны условия роста на пробных площадях № 3 и № 4, и наименьшей скоростью роста, наименьшим годичным радиальным приростом характеризуются деревья на ПП 1. Результаты анализа в целом совпадают с данными выполненной нами фитоиндикации плодородия почвы на основе встречаемости видов напочвенного покрова. Однако в целом отличия по приросту между рассматриваемыми площадями невелики и при ретроспективном анализе нестабильны - лидирующее положение по величине прироста в разные периоды роста демонстрируют хронологии с разных пробных площадей. Важно, что колебания величины прироста на всех четырех пробных площадях характеризуются высоким уровнем синхронности. Изложенное делает возможным объединение всех данных в единую выборку, для которой возможно рассчитать общее среднее (рис. 6) и вести дендрохронологическую диагностику, распространяя ее выводы на все древостои березы в пределах рассматриваемого кадастрового участка. 


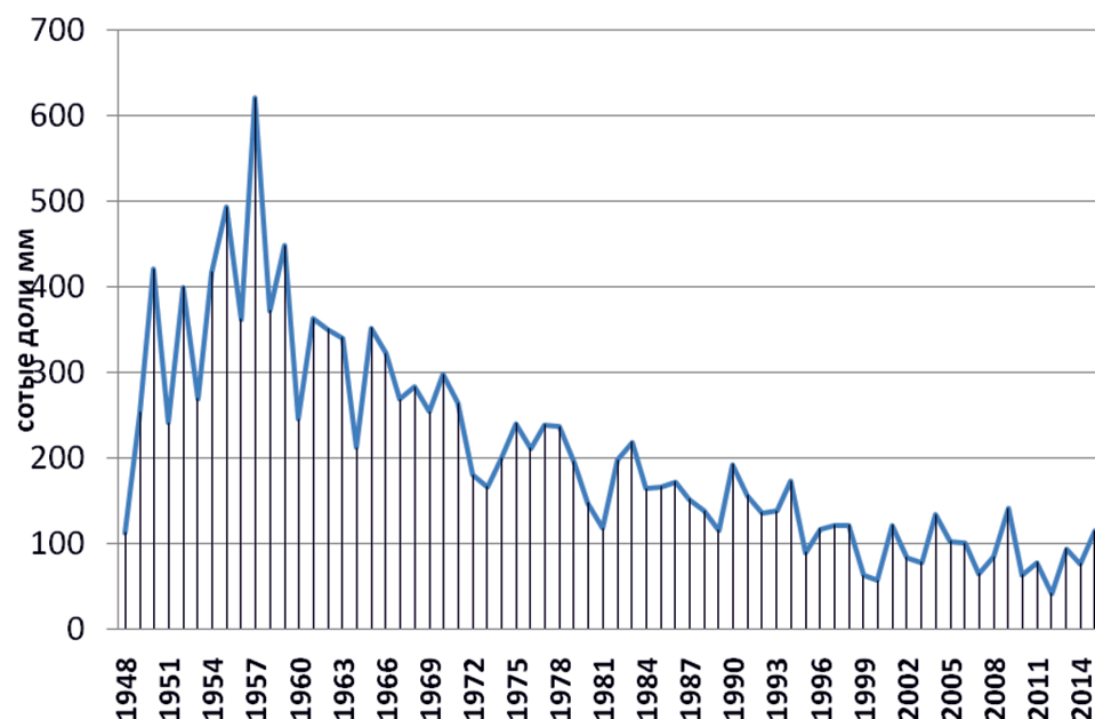

Рис. 6. Динамика средней ширины годичного кольиа у деревьев березы в условиях 30 квартала Домодедовского лесничества

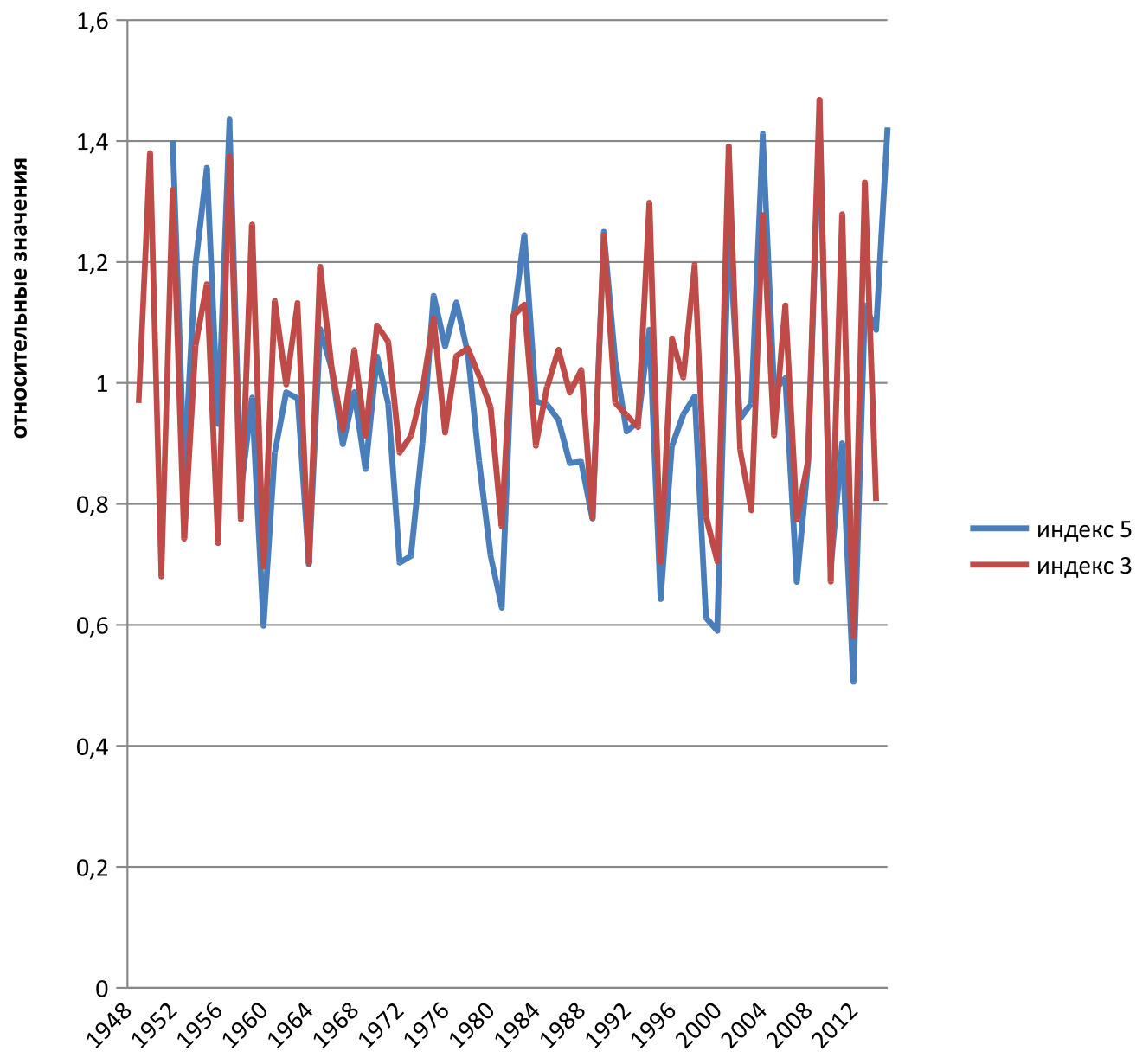

Рис. 7. Динамика индексов радиального прироста, рассчитанных двумя различными способами 
Анализируя долговременные тенденции изменчивости радиального прироста, в первую очередь необходимо отметить закономерное снижение ширины годичного кольца с возрастом. Это явление хорошо известно в дендрохронологии и носит название возрастного тренда. Для выполнения корреляционного анализа влияния климатических факторов на прирост необходимо провести математические преобразования рядов радиального прироста в ряды индексов радиального прироста [1]. Индексы радиального прироста были рассчитаны двумя способами. По первому ширина годичного кольца делилась на ширину годичного кольца за последние пять лет (индекс 5). По второму ширина годичного кольца делилась на средний прирост за три года: текущий, предыдущий и последующий (индекс 3). Анализируя динамику рядов индексов радиального прироста, можно отметить, что процедура индексации успешно удалила из временных серий долговременную тенденцию. При этом ряды индексов прироста несколько отличаются по размаху отклонений прироста. Расчет коэффициентов сходства демонстрирует высокое сходство между дендрохронологическими рядами: коэффициент корреляции равен 0,81, а коэффициент синхронности $87 \%$.

Для корреляционного анализа были использованы ряды метеоданных (среднемесячные температуры, месячные суммы осадков) метеостанции МГУ. При уровне доверительной вероятности 0,05 и числе степеней свободы 60 достоверны значения коэффициента корреляции от 0,25.

Результаты выполненных расчетов отражены на графиках (рис. 8, 9).

Таким образом, достоверные отрицательные корреляции с индексами прироста были обнаружены для среднемесячных температур июня текущего года (коэффициент корреляции $-0,40)$ и среднемесячных температур сентября прошлого года (коэффициент корреляции -0,32). Значения коэффициентов корреляции невелики и согласно шкале Чеддока свидетельствуют об умеренной тесноте связи между признаками. Можно заключить, что высокие положительные температуры июня могут оказывать отрицательное влияние на рост березы в исследуемых древостоях. Достоверных корреляций с осадками обнаружено не было.

Причины того, почему в высокобонитетных древостоях корреляционный анализ иногда оказывается неэффективным для решения упомянутых задач, были рассмотрены В.А. Липаткиным, Д.Е. Румянцевым и соавторами [7]. Отсутствие корреляционной связи между колебаниями прироста и колебаниями метеопараметров еще не говорит об отсутствии влияния климатических факторов на прирост стволовой древесины березы.

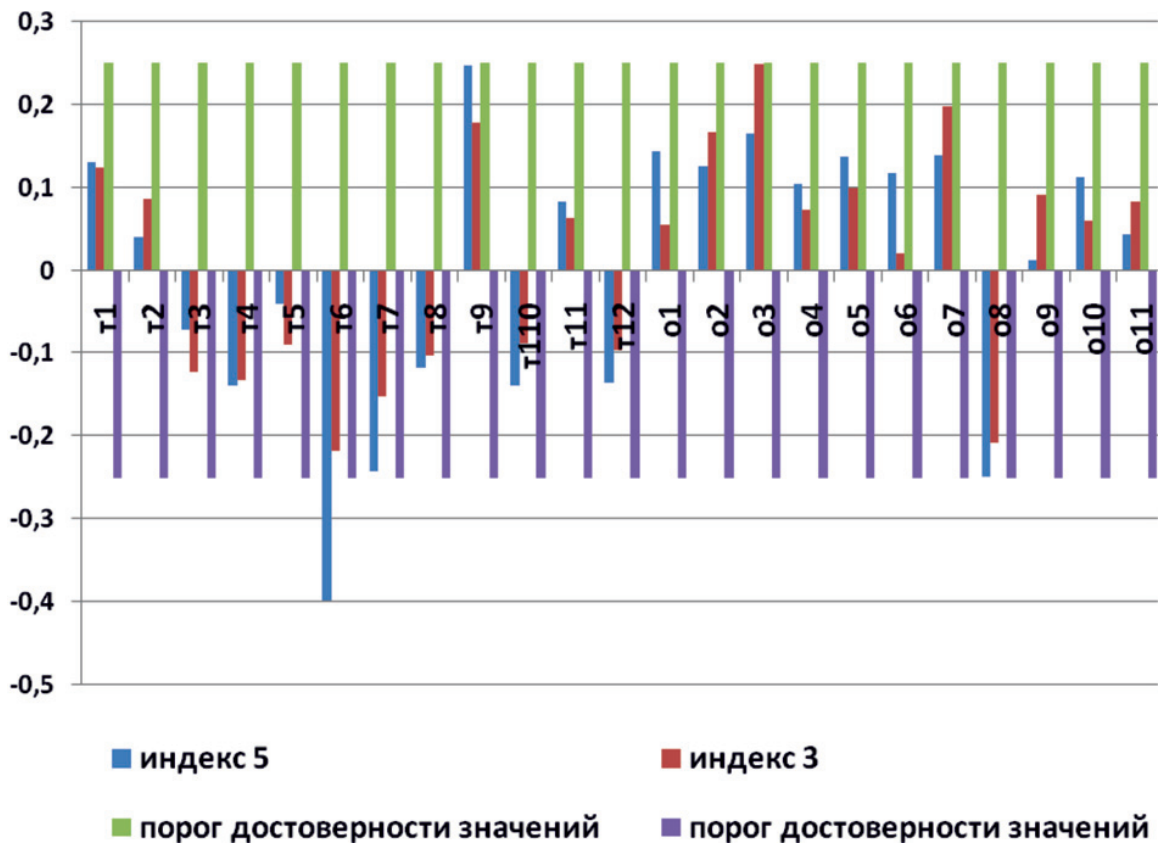

Рис. 8. Значения коэффициентов корреляции между индексами прироста и метеопараметрами текущего года 


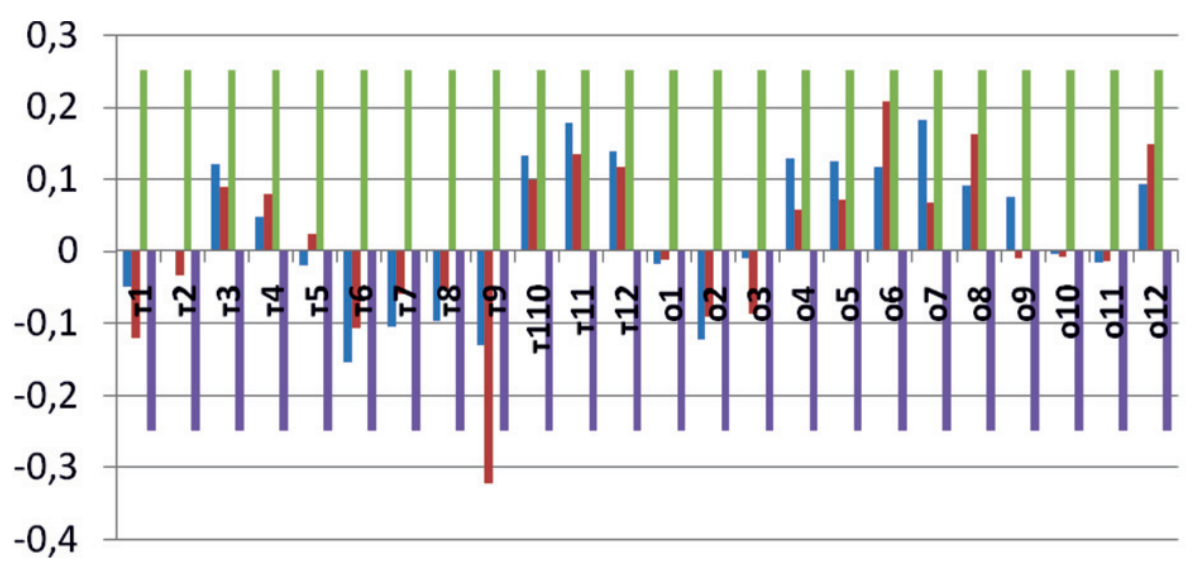

пндекс 5 индекс 3 порог достоверности значений п порог достоверности значений

Рис. 9. Значения коэффициентов корреляции между индексами прироста и метеопараметрами прошлого года

Могут иметь место эффекты аддитивности, антагонизма и синергизма в действии климатических факторов. Поэтому с точки зрения классических представлений в экологии полученные нами результаты следует объяснять тем, что насаждение находится в условиях, близких к оптимальным. Сильные отклонения от величины доз экологических (климатических) факторов как в большую, так и в меньшую сторону отрицательно сказываются на продуктивности березы.

Наличие одинаковой реакции прироста на разнонаправленные экстремальные отклонения дозы факторов от среднего, в совокупности со сменой лимитирующего фактора, от года к году снижает, таким образом, познавательную ценность процедуры корреляционного анализа. В дополнение к нему может использоваться разработанный на основе методологии работ Н.В. Ловелиуса [1] такой методический прием, как анализ климаграмм.

Согласно с этим методом выделяются годы экстремально высокого или годы экстремально низкого прироста. Рассчитываются средние показатели метеопараметров для этих лет. Далее сопоставляются средние значения метеопараметров для этих групп и среднемноголетних данных. Если метеофактор не влияет на прирост, то среднее значение метеопараметров для двух рассматриваемых групп совпадут. Если метеопараметр влияет на прирост, то зна- чения средних для двух групп будут существенным образом отличаться. Чем больше будет величина этих отличий, тем сильнее влияние фактора на прирост.

Такого рода сопоставление позволяет выявить экологические факторы, могущие выступать в качестве лимитирующих, высокую продуктивность и хорошее состояние древесных растений.

Анализируя графики (рис. 5, 6), можно выделить ярко выраженные годы минимумов прироста, повторяющиеся у большинства учетных деревьев на пробных площадях. К ним относятся 1951, 1953, 1956, 1958, 1960, 1964, 1973, 1981, 1989, 1995, 2007, 2012. Сопоставление средних показателей для рассматриваемых групп лет приведено на графиках на рис. 10 и 11.

Анализ климаграмм позволяет сделать вывод, что отрицательное влияние на рост и состояние деревьев березы в исследуемом насаждении могут оказывать пониженные суммы осадков в июне и июле, а также повышенные температуры воздуха в июне. Эти выводы корреспондируют с результатами корреляционного анализа. Водный дефицит в июне и июле является главным экологическим фактором, могущим вызывать плохой рост и состояние деревьев березы. Для улучшения состояния деревьев в посадке может быть рекомендован полив насаждений в июне и июле, в те годы когда осадков будет выпадать значительно ниже среднемноголетней нормы. 


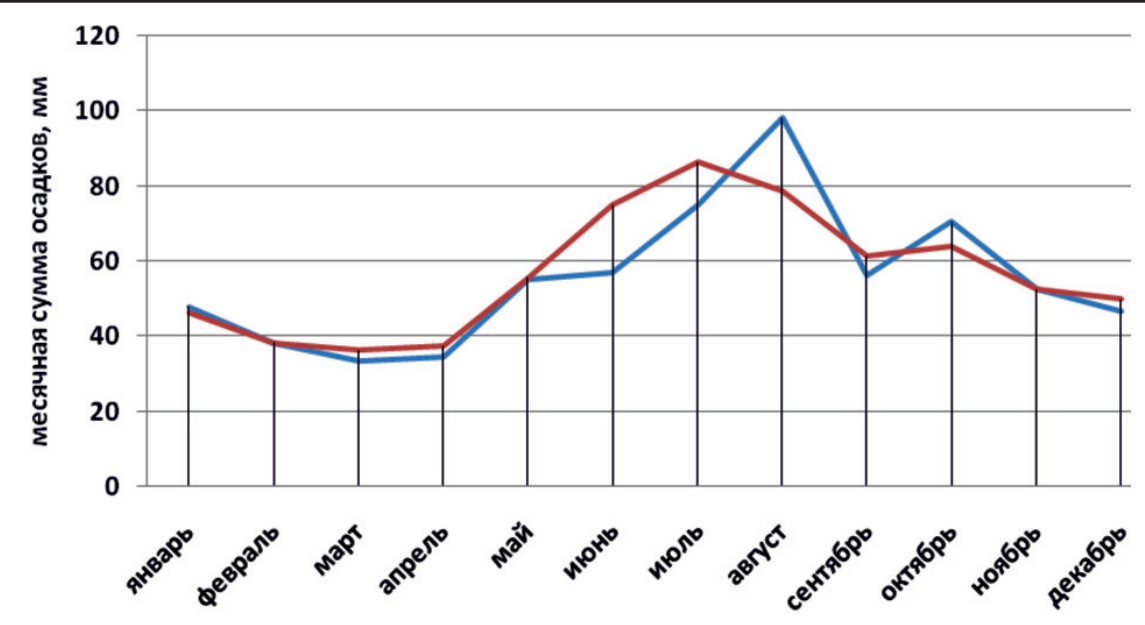

— Средняя для лет минимумов прироста

— Средняя многолетняя

Рис. 10. Сопоставление средних значений месячных сумм осадков: среднемноголетних показателей и средних по годам минимумов прироста

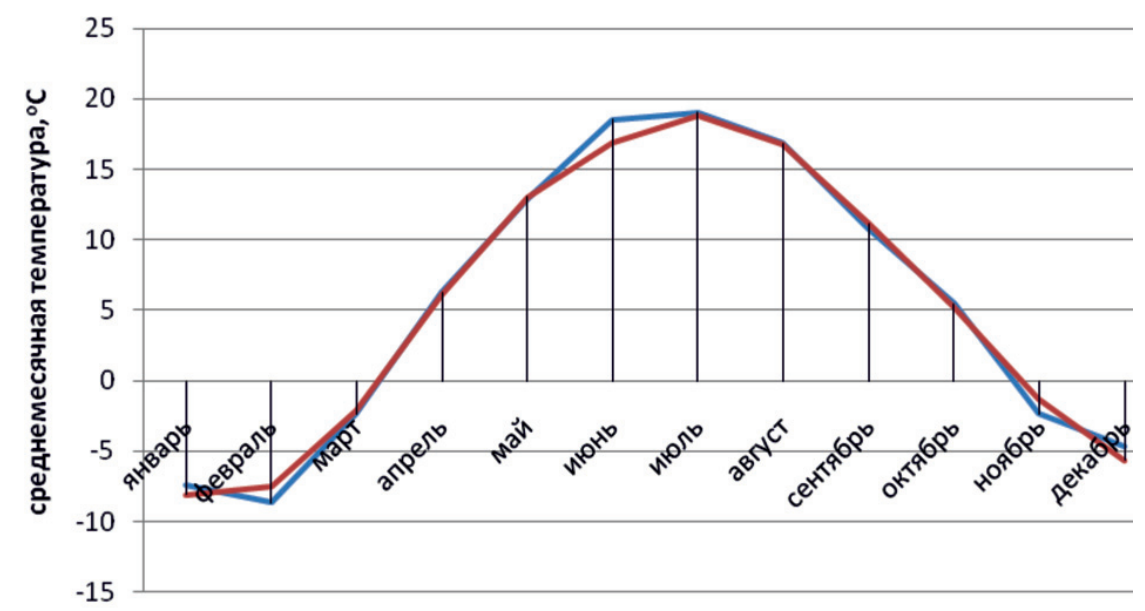

— Средняя для лет минимумов прироста —- Средняя многолетняя

Рис. 11. Сопоставление средних значений среднемесячных температур: среднемноголетних показателей и средних по годам минимумов прироста

\section{Заключение}

На основании выполненных дендрохронологических исследований были получены следующие основные выводы:

1. Исследуемые древостои относятся к VI классу возраста.

2. Все пробные площади, несмотря на наличие отличий по флористическому со- ставу подлеска и живого напочвенного покрова, характеризуются сходными условиями для роста и развития насаждений березы. Это делает возможным объединить дендрохронологическую информацию по всем пробным площадям в единую выборку и распространять полученные на основе ее анализа выводы на все древостои исследуемого участка. 
3. Древостои находятся в благоприятных условиях роста; лимитирующие прирост факторы меняются от года к году; отсутствует какой-либо ярко выраженный неблагоприятный климатический фактор, который бы регулярно отрицательно влиял на развитие исследуемых насаждений.

4. Для улучшения состояния насаждений, стимуляции радиального прироста в целях скорейшего зарастания ран и механических повреждений стволов может быть рекомендован полив деревьев в июне и июле в те годы, когда сумма осадков за эти месяцы будет значительно ниже среднемноголетних показателей по г. Москве.

\section{Список литературы / References}

1. Румянцев Д.Е. История и методология лесоводственной дендрохронологии. М.: МГУЛ, 2010.110 c.

Rumyantsev D.E. History and methodology of forest dendrochronology. M.: MGUL, 2010. 110 p. (in Russian).

2. Зайцев Г.А. Радиальный прирост березы повислой в условиях Елецкого промышленного центра // Материалы VIII Международной научно-практической конференции «Экология и природопользование: прикладные аспекты». Уфа: БГПУ, 2018. С. 136-140

Zaytsev G.A. Radial increase of birch in the conditions of the Yelets industrial center// Proceedings of the VIII International scientific and practical conference «Ecology and environmental management: applied aspects». Ufa: BGPU, 2018. P. 136-140 (in Russian).

3. Баландайкин М.Э. Влияние Inonotus Obliquus (Pers) Pil. на радиальный прирост ствола и индекс асимметрии флуктуаций фотосинтетических тканей березы повислой // Ярославский педагогический вестник. 2012. Т. 3. № 3. C. $72-85$.

Balandakin M.E. Influence of Inonotus Obliquus (Pers) Pil. on the Radius Growth and the Index of Asymmentry of Fluctuations of Photosynthetic Tissues of Betula Pendula // Yaroslavl Pedagogical Bulletin. 2012. T. 3. № 3. P. 72-85 (in Russian).

4. Толкач О.В. Изменение годичного радиального прироста березы, дефолиированной непарным шелкопрядом Lymantria Dispar (L.) // Современные проблемы науки и образования. 2013. № 6 [Электронный ресурc]. URL: http:// science-education.ru/ru/article/view?id=11470 (дата обращения: 23.01.2019).

Tolkach O.V. Change in annual radial growth of birch, depolimerizovannogo Gypsy moth Lymantria Dispar (L.) // Modern problems of science and education. 2013. № 6 [Elec- tronic resource]. URL: http://science-education.ru/ru/article/ view?id=11470 (date of access: 23.01.2019) (in Russian).

5. Хамидуллина М.И. Взаимосвязь годичного радиального прироста березы повислой (Betyla Pendula Roth.) с гидротермическими условиями, предшествующими вспышке массового размножения непарного шелкопряда (Lymantria Dispar L.) в лесах Свердловской области // Аграрный вестник Урала. 2008. № 9. С. 70-71.

Khamidullina M.I. The relationship of annual radial growth of birch (Betula Pendula Roth.) with hydrothermal conditions preceding the outbreak of mass reproduction of unpaired silkworm (Lymantria Dispar L.) in the forests of the Sverdlovsk region // Agrarian Bulletin of the Urals. 2008. № 9. P. 70-71 (in Russian).

6. Вахнина И.Л., Малых О.Ф. Деградация березняков бассейна реки Аргунь как показатель климатических изменений // Вестник Красноярского государственного университета. 2013. № 4. С. 122-126.

Vakhnina I.L., Malykh O.F. The Argun River Basin Birch Forest Degradation As The Climatic Change Indicator // Bulletin of Krasnoyarsk state University. 2013. № 4. P. 122-126 (in Russian).

7. Липаткин В.А., Румянцев Д.Е., Стоноженко Л.В., Коротков С.А., Крылов А.М. Выявление климатической обусловленности в колебаниях радиального прироста ели методом корреляционного анализа: обсуждение адекватности подхода и причин возникающих затруднений // Дендрохронологическая информация в лесоводственных исследованиях. Под ред. В.А. Липаткина, Д.Е. Румянцева. М.: МГУЛ, 2007. C. $113-124$.

Lipatkin V.A., Rumyantsev D.E., Storozhenko L.V., Korotkov S.A., Krylov A.M. Identification of the climatic conditionality of the fluctuations in the radial growth of spruce using correlation analysis: a discussion of the adequacy of the approach and the reasons for constraint $\mathrm{s} / /$ Dendrochronological information in forestry researches. Under the editorship of V.A. Lipatkin, D.E. Rumyantsev. M.: MGUL, 2007. C. 113-124 (in Russian).

8. Румянцев Д.Е., Фролова В.А., Даньшина Т.В. Радиальный прирост березы в разных типах леса в условиях Домодедовского лесничества Московской области // Современные проблемы науки и образования. Сборник трудов конференции. М.: Издательский дом Академии Естествознания, 2018. С. 80-83.

Rumyantsev D.E., Frolova V.A., Danshina T.V. Birch radial growth in different types of forest in the conditions of Domodedovo forestry of the Moscow region // Modern problems of science and education. Collection of works of a conference. M.: Izdatel`skij dom Akademii Estestvoznaniya, 2018. P. 80-83 (in Russian).

9. Рысин Л.П., Полякова Г.А., Савельева Л.И. и др. Леса Москвы. Опыт организации мониторинга. М.: ИЛ РАН, 2001. 148 c.

Rysin L.P., Polyakova G.A., Savelyev L.I., etc. Forests of Moscow. Experience in the organization of monitoring. M.: IL RAN, 2001. 148 p. (in Russian). 